James McDougall (éd.), "Nation, Society and Culture in North Africa", Journal of North African Studies, vol.8, $\mathrm{n}^{\circ} 1,2003,35-42$.

An earlier version of this article was presented to the Tunisian Association for the Promotion of Film Criticism (ATPCC) in Tunis in 1994. Feature-length films produced in Tunisia since 1956 now (September 2002) number around 100. The production examined here consists of those 60 or so films made in the first 40 years of Tunisian independence.

\title{
IdeOlOGies OF THE NATION IN TUNiSiAn Cinema
}

KMAR Kchir Bendana

What is Tunisian cinema? Or, what do we understand by 'Tunisian' cinema? Would it be simply the totality of films produced since the country's independence by directors of Tunisian nationality, in Tunisian studios with Tunisian crews and budgets? Or all films shot in Tunisia? These criteria, which are national' at least in the sense of juridical and financial nationality', are generally appropriate in respect of the 60 or so films which can be considered as constituting a corpus of contemporary (that is, post-independence) Tunisian cinematography. The considerations which I shall develop here revolve around a central question, that of understanding what is signified by 'Tunisian', or tunisianité, and are intended as an attempt to read, through the diverse marquetry of cultural production represented by these films, the various meanings which they give to the 'nationality' they apparently share.

What can we understand by 'tunisianité'? And how is such a national identity expressed through such varied artistic works? Or rather, how does the ideological expression of 'the national' manifest itself, on different levels, according to different viewpoints and approaches? in other words, what we are seeking to isolate, in sociological terms, is the relation between the material bases of social organisation and the most highly elaborated forms of intellectual, artistic and cultural production; taking the Tunisian cinema as a case study, I observe in this article the field constituted by 40 years' production of films in order to test a grille de lecture, experiment with certain definitions, and advance a certain number of hypotheses.

Since I have raised the notion of 'ideology', I should first of all explain which of ail its definitions I mean - although several would suit the present purpose. Among them - ideology as the science of ideas (as facts of consciousness, their nature and laws), or, by extension, the study of a system of ideas, that is, of a philosophy of the world and of life or, again, as a classical Marxist reading would have it, the totality of ideas and beliefs particular to a given global historical period, society or class - I opt for the point of view presented by Althusser, that ideology is the imaginary relation of individuals to their real conditions of existence. ${ }^{1}$ The term thus designates the totality, not only of representations, but also of practices and behaviour both conscious and unconscious. 'National identity' here does not, then, mean the supposedly 'objective' criteria held to characterise a nation - territorial space, language, and juridical considerations were only just appropriate for the initial steps towards an insufficient definition with which we began. To 'belong to a nation' is to adhere, voluntarily or not, consciously or not,

\footnotetext{
${ }^{1}$ 'L'idéologie et appareils idéologiques d'Etats', La Pensée (June 1970). Reprinted in English, 'Ideology and Ideological State Apparatuses' in Louis Althusser, Essays on Ideology (London: Verso 1984).
} 
to a representation - not to a political regime, nor to a doctrine or a culture, but to the framework within which all of these are expressed, the ideological form of modern social community. ${ }^{2}$ An idea, or ideology, of the nation is not reducible to nationalism, and vice versa; nationalism might rather be thought of as one possible form of expression of the broader system of a national ideology, a form most often today identified as pathological, as a hypertrophy of national sentiment. For our purposes here, I consider 'nationalism' as one level of ideological expression which might be encountered in the reading of our corpus of films - in official discourse, in propaganda, in underlying assumptions - but which might equally be encountered, diffused or explicit, in the writing of some of our films' critics. There are, for example, certain affirmations made here and there in the press or in literature on the subject which deserve attention. Tunisian cinema has a 'national tonality' less acute than that of its Algerian neighbour ${ }^{3}$ (where 'national' means what I call 'nationalist'). Tunisian cinema in the 1970s arrived at a certain 'Tunisian ethic'; ${ }^{4}$ the same decade is said to have witnessed the creation of a 'national cinematographic aesthetic'. ${ }^{5}$ Such question-begging uses of the terms 'Tunisian' and 'national' oblige us to interrogate the films themselves in order to investigate what is meant by their being 'Tunisian' or 'national', and what is the ideology of the national in this 'Tunisian' cinema.

One attitude, common to a certain number of films, and whose decoding is extremely simple, is first and most obviously remarkable. Pure political engagement marks those films which take as their subject the political history of nationalism, exalting with a certain gusto a glorious national history, relating the struggle for the country's political liberation from colonialism. One thinks in particular of the films of Omar Khlifi, a director whose début, al-Fajr ('The Dawn') of 1966, is considered the first Tunisian film. He would go on to make three further films: Le rebelle, ('Rebel', 1968); Les fellaghas, ('Bandits', 1970); and Hurlements, ('The Roaring', 1972). Khlifi produced a cinema which relates and illustrates in its images exactly what is produced and reproduced by school history books, radio and television programmes, and all the official public histories. These films define themselves as national because they are nationalist. Their content and tone is determined by what 'the nation' says, tells itself, and teaches about itself. The struggle against colonialism is idealised, presented as a uniformly heroic enterprise in such a way as to serve directly, through cinema, the project of constructing a nationalist epic in line with a state-sponsored cultural production dominated by unanimism. The creation of the production company SATPEC (Société Anonyme Tunisienne de Production et d'Exploitation Cinématographique) in 1959, and then the building of a film laboratory at Gammarth, completed in 1967, were essentially political decisions, intended to give the new national cinema an infrastructure which would allow it to develop.

The recent history which the first films set out to dramatise, of Course, was not nearly so simple and Manichean as it appears in Khlifi's work. Other directors, recognising the forgotten aspects of official history, revisited it, attempting to repair earlier omissions and tackling subjects which are not generally mentioned in treatments of the country's recent past. Abdellatif Ben Ammar's Sejnene (1973 - the title is taken from the name of a small agricultural and mining town in northern Tunisia) dealt with the workers' movement, rereading the history of national liberation through the story of the UGTT (Union Générale des Travailleurs Tunisiens, the Tunisian General Workers' Union, founded in 1946). Through the story of a print-worker and his son seen during the events of 1952-54, a crucial period of contemporary Tunisian history,

\footnotetext{
${ }^{2}$ See the remarks of Pierre Nora, 'Présentation' in Les lieux de mémoire, vol.I, La nation (Paris: Gallimard 1986), especially, p.x.

${ }^{3}$ Guy Hunebelle, in Férid Boughedir, Introduction aux Cinémas du Maghreb, special issue of Ciném'Action, (Paris, 1980) p.6.

${ }^{4}$ Victor Bachy, Le cinéma de Tunisie, 1956-77, (Tunis: STD 1978) p.147.

${ }^{5}$ Férid Boughedir (note 3) p.67.
} 
the director sought to restore to the labour movement as a whole its place in the anticolonial struggle. Et Demain, ('And Tomorrow', 1972) by Brahim Babaï confronted two crucial problems of the immediate post-independence period - unemployment and the exodus from the countryside. The condition of immigrants in France was the burning subject of the moment when Naceur Ktari made Les Ambassadeurs in 1975. The film, set in the Goutte d'Or district of Paris (an area heavily populated by North African immigrants), plays on the grandiloquent and misleading title of 'ambassadors' given by the authorities at home to the migrants, whose living and working conditions give the lie to rosy official rhetoric.

Women, although never absent from the more 'officially' nationalist films, (Khlifi's Hurlements, for example), became heroines in their own right in this second category, which seemed intent on giving women the place of honour in a 'revised and corrected' national history whose task was the rehabililation of all those who had previously been forgotten. This was thus a cinematography whose political engagement had a revisionist agenda, but its desire to testify about Tunisian society and history was nonetheless articulated in the same affirmative register as more 'traditional' nationalism. This is true even of a film like Sejnene, which, despite its highly original viewpoint, did not depart from the fixed chronological scheme of those key dates accepted by everyone, more or less, as developmental steps of the national movement and through which the history of the struggle for liberation is told via that of the political parties. When, in Soleil des Hyènes ('Hyenas Sun', 1976), Ridha Behi mounted a critique in which the ravages of the tourist industry were perceived as acts of rape, (the film showed the brutally penetrative impact of the expansion of tourism in a fishing village, where the new economy smashes social relations, the labour market, the landscape, and property rights...) it was, again, a question of affirming the 'defence of the nation'. Brahim Babaï was working from a similarly nationalist perspective in composing his political statement, La Nuit de la Décennie (1990) which dealt with the causes of the 1978 clashes between the regime and the workers' union. All these films have a second common denominator. They all focus on characters who generally lack consistency and exist only as symbolic flag wavers. Even when, in the best works, the characters have a certain depth, they nonetheless remain prisoners of prototypes: the traitor, the patriot; the bourgeois, the worker, the woman - a necessarily positive character - the colonist, the intellectual, the bureaucrat. The ideology of the nation is thus expressed through a gallery of highly characteristic 'Tunisians'! Despite their entirely different genres - since they are, variously, Western-style epics, neo realist statements or quasi-documentary reportages, these films exhibit the same tendency to address tunisianite through a typology of more or less archetypal characters.

Other film makers, nonetheless, understood the impossibility of determining exactly what 'the national' signifies, appreciating that no representation of social or political history can ever exhaust the question of tunisianité by giving it a total and definitive form. Their films express in a more nuanced fashion the ambiguities and difficulties of being Tunisian. The 1969 film Khlifa Lagraa ('Khelifa the Bald') is emblematic of this approach. Director Hamouda Ben Halima describes with great individuality and a highly poetic economy of style the malaise of a man exceptionally authorised (or condemned) to enter the closed and private world of women by a skin disorder which leaves him bald. A few years later, Au Pays de Tararini, (1972) a collective film made up of short cinematic sketches, evoked the old city of Tunis. In its best moments achieving a level of refinement and intimacy comparable with those of Ben Halima's Khlifa Lagraa, the film sought to anchor itself in a mythical past, and represents the first appearance of what might be called the nostalgic side of Tunisian cinema. The past is reasserted, here, in warm retrospection, but can the return to certain values and sources of the urbane Tunisois, thus reclaimed through a certain stylised imagery, constitute the hallmark of tunisianité? An explicit 
interest in the work of Tunisian novelists characterises this tendency, which finds its legitimate subjects (Khelifa le Teigneux, Tararini, Barg Ellil) in the writings of Ali Douaji ${ }^{6}$ and Bechir Khraïef. $^{7}$

Curiously, a film as radical and Brechtian as the Nouveau Théâtre's La Noce ('The Wedding') can also be considered, at least as regards its dialogue, as representative of this nostalgic current. However different the films undoubtedly are in form, La Noce (1978) can be read alongside Ali Labidi's Barg Ellil (1990) which relates in a conventional, televisual style a story of life in Tunis in the fifteenth century, at the time of the Spanish invasion, as weil as Halfaouine, L'enfant des terrasses (1990) in which Ferid Boughedir amuses himself with his childhood memories, Soltane el Madina, (1992) Moncef Dhouib's reflection on the degeneration of the old town's districts, or more recently Les Silences du Palais (1994), a film by Moufida Tlatli in which the action takes place around the end of the beylicate in the 1950s. In all these films one can observe a particular attention paid to language in the scripting of the dialogues, which most frequently employ a tunisois dialect, vehicle of a certain, specific notion of tunisianité which is reductive and not, of course, shared by all.

For other directors, Tunisian identity is to be found in the countryside. Taïeb Louhichi's L'Ombre de la Terre ('The Shadow of the Land'), (1982) a chronicle of the life of a nomadic community at the edge of the desert, is the most significant example of a group of films which have sought to glorify the rural world; Ali Abdewahab, in Om Abbès (1969), and Omar Khlifi in Hurlements (1972), also attached themselves to the effort of rehabilitating with a great deal of theatricality and rather less accuracy - a bedouin world that had been abandoned and ignored.

A further attempt to problematise dominant notions of 'national identity' emerged in work addressing the delicate question of biculturalism and plural identity, a tendency which emerged relatively early in Tunisian cinema with films like Mokhtar (1968) by Sadok Ben Aïcha, which related in episodic fragments the suicide of a young, francophone Tunisian novelist, and Une si Simple Histoire (1970) by Abdellatif Ben Ammar, who demanded of his audience a reflection on the déchirement of a Tunisian intellectual married to a Frenchwoman. The same director's Aziza (1980) similarly explored the difficulties of adapting from traditional ways of life to modern living, through the emigration of an artisan from the heart of the old medina, symbol of a disappearing socio-cultural urban network, to a newly built suburb. The changes in socio-economic conditions and values observed through this spatial shift appear limitless, as one of the characters, Aïcha, leaves with a Gulf emir, dazzled by the mirage of an easy life which marriage to him seems to offer.

A concern with boundaries, borders and imposed limitations also animates Mahmoud Ben Mahmoud's Traversées (1982), whose action takes place outside Tunisia, and relates the painful failure of the attempted 'crossings' of the title through the story of a Tunisian intellectual's inability to cross a European frontier. More recently, Chichkhane, ('Diamond Oust', 1991) by Mahmoud Ben Mahmoud and Fadhel Jaïbi, and Les Zazous de la Vague, (1992) by Mohamed Ali Okbi, both explore (the latter in parodic mood) the complexity of a 'Tunisian identity' subject to the countervailing forces which pull their characters in different directions: these two films address, respectively, cultural mix, and the refusal to accept one's condition in life. The cohabitation of - at least - two identities, 'eastern' and 'western', is treated here in quite different ways, sometimes in a grave and even tragic tone (as in Diamond Dust), alternatively in

\footnotetext{
${ }^{6}$ (1909-49) A Tunisian novelist and short story writer, he was a member of the famous literary and artistic group Taht Essour ('Below the Ramparts') and also wrote radio plays, song lyrics.

${ }^{7}$ (1917-83) A writer, born in the Tunisian south, of novels and novellas which were serialised in the Tunis press, notably in the review al-Fikr
} 
In such films, which demonstrate a particular sensitivity arrived at through the development of cinematography in Tunisia more generally, it becomes possible to identify particular expressions of locality and singularity. The appearance of film makers working in this vein, such as Néjia Ben Mabrouk and Nouri Bouzid, consecrated an interest in film capable of scrutinising its characters, one which would endow them with a psychological density transcending simple typologies. Around the characters of their films, these directors construct a meticulously precise and realistic vision of space, décor and dialect, creating a specific ambiance and constituting a depth and sincerity for their protagonists, heroes who can finally be apprehended in the full complexity of their contradictions. Earlier works, it is true, had already given a foretaste of this achievement: well before Néjia Ben Mabrouk's La Trace (1982) or the 1986 production L'Homme de Cendres by Nouri Bouzid (a true homage to the old city of Sfax), Ahmed Khéchine, in his 1969 film Sous la Pluie de l'Automne, succeeded in depicting the conflicts of a poor family in Kairouan with a remarkably sure eye and tone - albeit without ever liberating himself from suppositions about 'the national' as a pre-existing given simply requiring illustration, rather than a problem in need of creative exploration. The culmination of this approach can be seen in Nouri Bouzid's sketch, C'est Schéhérazade qu'on assassine ('Murdering Sheherazade') in the collective film La Guerre du Golfe et Après...(1992), which addresses the 1991 war in the Gulf, an event translated into a spectacular worldwide phenomenon by its televisual hyper-mediatisation, through the lens of the everyday life of a Tunisian family. The director, concentrating his gaze on small, tightly circumscribed facts, succeeded in exposing a larger reality, one which gained the film a considerable audience. It is, in fact, local, particularistic films, assuming their specificity and presenting it in a way which is globally accessible, which have more recently achieved the greatest success at Tunisian box offices, and which have also most attracted foreign audiences: witness the popular success of Halfaouine, L' Homme de cendres and Les Silences du Palais.

Yet other directors have opted to ignore, or to refuse, the flagging of national colours; in such films, where some notion of tunisianité is not immediately evident, we might ask ourselves what significance such an absence might have. In establishing an ad hoc inventory of these films it is quickly apparent that they appeared very early on in Tunisian cinema - films which played on allegory or which effaced certain stock themes of 'Tunisianness'. In Yusra, (1972) Rachid Ferchiou set the action of his fantastic tale in an indeterminate Mediterranean space, as if to accentuate its ethereal aesthetic. Claude d'Anna and Férid Boughedir's La Mort Trouble (1969) explored the master-slave problematic, but in an esoteric style, to investigate the colonial situation from an oblique angle. The Nouveau Theatre's Arab (1988) equally employed the detour of metaphor - in this case, the siege of a derelict cathedral- to explore the threats posed to Tunisia by conflicts in other Arab states, whereas Les Baliseurs du Désert, a (1984) film by Naceur Khémir, took refuge in allegory, beyond the limitations of any specific time, to pursue its search for the meaning of lost cultural values.

There is, too, a further wave of films - Mon Village (1979) by Mohamed Hammami, in which the village of the title is that of a group of Palestinian fida'iyin; Leila ma Raison (1989, the plot is that of a famous, seventh century Arabian legend, mediated through a novel by André Miquel of which the screenplay is an adaptation) by Taïeb Louhichi; La Ballade de Mamelouk (1982) by Hafedh Bouassida; Les Anges, (1984); Champagne Amer, (1986), and Les Hirondelles ne meurent pas à Jérusalem (1994), by Ridha Béhi; and finally Naceur Khémir's Le Collier Perdu de la Colombe (1988). The makers of these films, perhaps for reasons of marketing and distribution, have deliberately chosen as their setting spaces which evoke Tunisia only indirectly, if at all. Their screenplays, too, employ foreign languages or dialects, or 
else are couched in literary Arabic, or in an artificial, 'rootless' Arabic, supposedly comprehensible anywhere and thus capable of carrying tunisianité - whatever their tunisianité would then be - into a market-place otherwise inaccessible to an overly specific local ('national') production. Work in this vein, sacrificing local particularity, has yet to prove its commercial and artistic effectiveness, and the allegorical detours through which it finds expression demonstrate in themselves the difficulties of 'speaking the national' through film and, thereby, also themselves speak of the complexity which 'Tunisian', if these are 'Tunisian' films, entails.

The brief, panoramic overview which I have attempted to sketch illustrates the variety of Tunisian film-makers' responses to the question of 'the national', whether the question itself is central to their preoccupations or uncomfortably lingers on the periphery of their vision. The inescapability, in any event, of 'national' classification, of 'being national', in whatever sense, and somehow expressing an ideology of the nation, is perhaps a reflection of the overwhelming dominance of what Balibar calls the 'nation-form' ${ }^{8}$ in global political and ideological organisation. Contemporary Tunisian cinema is obliged to organise and present itself as a 'national cinema' in a market where it has to face other national cinemas - Algerian, Egyptian, French - and all others (Indian, British, Italian cinema) do likewise, in the face of American cinema, which alone, perhaps, in the global marketplace is capable of transcending (or sufficiently extending?) its own frontiers and specific traits, and of imposing itself as 'translational'.

\footnotetext{
${ }^{8}$ Etienne Balibar, 'The Nation Form: History and Ideology', in E. Balibar and Immanuel Wallerstein, Race, Nation, Class: Ambiguous Identities (London: Verso 1991).
} 